\title{
Associations of Herbicides on the Simultaneous Control of Horseweed and Italian Ryegrass
}

\author{
Lucas de Ross Marchioretto $^{1}$, Bruno Vicente Basso Ferrazzi ${ }^{1}$, Taísa Dal Magro ${ }^{1} \&$ Elaine Damiani Conte ${ }^{1}$ \\ ${ }^{1}$ University of Caxias do Sul, Vacaria, RS, Brazil \\ Correspondence: Lucas de Ross Marchioretto, University of Caxias do Sul, Vacaria, RS 95200-000, Brazil. Tel: \\ 54-3908-5400. E-mail: lucasdeross@hotmail.com
}

Received: December 25, 2017

Accepted: January 29, 2018 Online Published: March 15, 2018

doi:10.5539/jas.v10n4p150

URL: https://doi.org/10.5539/jas.v10n4p150

\begin{abstract}
Weed competition negatively affects grain yield on wheat and soybean crops. Due to better practicality and timesaving it is usual the association of broadleaf herbicides with graminicides to control monocot and dicot weeds. However, little is known about the deleterious effects of broadleaf herbicides on graminicides. Thus, the objective of this experiment was to evaluate the effects of simple, double and triple association of broadleaf herbicides with graminicides to control of Italian ryegrass and horseweed. The experiment was conducted into greenhouse on completely randomized experimental design with four replications. The treatments consisted of the graminicides clethodim and clodinafop; the broadleaf herbicides 2,4-D, metsulfuron and saflufenacil and non-selective glyphosate, sprayed isolated and in double and triple association to be compared with a control. The variables evaluated were control (\%) at 21 and 28 days after treatments (DAT), and dry weight (g) at 28 DAT. The isolated graminicides and the broadleaf herbicides controlled both Italian ryegrass and horseweed respectively. At the double association of broadleaf with graminicides herbicides, 2,4-D antagonized the effect of clodinafop, and glyphosate mixed with clodinafop decreased the control of the graminicide on Italian ryegrass. At the triple herbicide association, when mixed with glyphosate, metsulfuron decreased the control effect of Italian ryegrass by clethodim. The association of broadleaf herbicides with graminicides is effective on the control of monocot and dicot weeds, but it depends on which herbicide used for the combination. When it is evident the antagonism between broadleaf herbicides and graminicides, the detrimental effects go on grass control.
\end{abstract}

Keywords: Conyza spp., Lolium multiflorum, antagonism, synergism, chemical control

\section{Introduction}

The Italian ryegrass (Lolium multiflorum) and horseweed (Conyza spp.) are weed plants of occurrence in winter and spring crops in Southern Brazil. The weeds begin their germination during the winter and complete their life cycle in spring. In Brazil, there are some horseweed biotypes that present resistance to the herbicides: glyphosate, chlorimuron, paraquat, and saflufenacil including some biotypes with multiple resistance to glyphosate, chlorimuron and paraquat (Heap, 2017; Vargas, Bianchi, Rizzardi, Agostinetto, \& Dal Magro, 2007) and Italian ryegrass resistant to glyphosate and iodosulfuron besides three biotypes with multiple resistance being: glyphosate and clethodim; clethodim and iodosulfuron; and glyphosate, iodosulfuron and pyroxsulan (Heap, 2017; Vargas, Roman, Rizzardi, \& Silva, 2005).

Broadleaf herbicides such as 2,4-D, metsulfuron and saflufenacil are reported as effective alternatives on the control of glyphosate resistant horseweed (Vargas et al., 2007; Eubank, Nandula, Reddy, Poston, \& Shaw, 2013). Whereas, inhibitors of the acetyl coenzyme A (ACCase) graminicides are effective to control glyphosate resistant Italian ryegrass (Vargas et al., 2005).

The coexistence of wild radish (Raphanus spp.) and Italian ryegrass decreases the dry weight accumulation and the number of tillers of the wheat crop, beginning at the 42 days after the crop's emergence; besides, when the wheat crop coexists with the weeds, the stems of the crop tend to be longer (etiolated) compared to wheat plants without grown competition. This happens because the wheat plant competes for light with the weeds (Agostinetto, Rigoli, Schaedler, Tironi, \& Santos, 2008). In the soybeans crop, the infestation of one horseweed plant per square meter throughout 81 days at the cropping site decreases about $36 \%$ yield due to a decline in the 
number of branches and pods per plant caused by competition (Trezzi, Vidal, Patel, Miotto, Debastiani, Balbinot, \& Mosquen, 2014).

The association (tank-mixture) of herbicides of different modes of action are usual at the cropping systems looking to control some troublesome glyphosate resistant weeds. Whereas, when monocot and dicot weeds are present at the same cropping system, in which glyphosate alone is not capable to satisfactorily controlling, it is necessary to associate graminicides and broadleaf herbicides aiming to control these weeds, as it is more practical, timesaving and avoids the constant traffic of agricultural equipment leading to soil compaction. Nevertheless, little is known about the effects of the association of broadleaf herbicides with "dim" or "fop" graminicides (ACCase inhibitors) on the control of horseweed and Italian ryegrass of simultaneous occurrence. Thus, the objective of this trial was to evaluate the effects of simple, double and triple level of herbicide association on the control of horseweed and Italian ryegrass.

\section{Material and Methods}

\subsection{Local of the Study}

The experiment was carried out in a greenhouse at the University of Caxias do Sul located at the municipality of Vacaria, Rio Grande do Sul, Brazil (28²9'20.6"S; 5056'14.2"W; 971 meters above sea level).

\subsection{Subject of Study}

Horseweed (Conyza spp.) and Italian ryegrass (Lolium multiflorum) seeds, coming from cropping fields from the region of the experiment were sown on trays containing soil, and when they reached the growth stage of three to four leaves the plantlets were transplanted on plastic pots with one liter of volume, filled with soil (oxisol). The plants were irrigated always when necessary.

\subsection{Treatments}

It was conducted three experiments aiming to test the control effectiveness and the compatibility of herbicides associations of the graminicides clethodim and clodinafop, the broadleaf herbicides 2,4-D, metsulfuron and saflufenacil, and the non-selective herbicide glyphosate, all sprayed isolated, in double, and triple association, sprayed in horseweed and Italian ryegrass as follows:

\subsubsection{Herbicides Alone}

The treatments consisted of an untreated control and the broad leaf herbicides 2,4-D (1005 $\left.\mathrm{g} \mathrm{ha}^{-1}\right)$, metsulfuron $\left(4 \mathrm{~g} \mathrm{ha}^{-1}\right)$, and saflufenacil $\left(49 \mathrm{~g} \mathrm{ha}^{-1}\right)$, the graminicides clethodim $\left(108 \mathrm{~g} \mathrm{ha}^{-1}\right)$, clodinafop $\left(60 \mathrm{~g} \mathrm{ha}^{-1}\right)$, glyphosate $\left(1800 \mathrm{~g} \mathrm{ha}^{-1}\right)$.

\subsubsection{Herbicides in Double Association}

The treatments consisted of an untreated control and the associations of graminicides with the broadleaf herbicides: 2,4-D+Clethodim $\left(1005+108 \mathrm{~g} \mathrm{ha}^{-1}\right), 2,4-\mathrm{D}+$ Clodinafop $\left(1005+60 \mathrm{~g} \mathrm{ha}^{-1}\right)$, Metsulfuron+Clethodim $\left(4+108 \mathrm{~g} \mathrm{ha}{ }^{-1}\right)$, Metsulfuron+Clodinafop $\left(4+60 \mathrm{~g} \mathrm{ha}^{-1}\right)$, Saflufenacil+Clethodim $\left(49+108 \mathrm{~g} \mathrm{ha}^{-1}\right)$, Saflufenacil+Clodinafop $\left(49+60 \mathrm{~g} \mathrm{ha}^{-1}\right)$; and the associations of each herbicide with glyphosate: Glyphosate+Clethodim $\left(1800+108 \mathrm{~g} \mathrm{ha}^{-1}\right)$, Glyphosate+Clodinafop $\left(1800+60 \mathrm{~g} \mathrm{~h}^{-1}\right)$, Glyphosate $+2,4-\mathrm{D}$ $\left(1800+1005 \mathrm{~g} \mathrm{ha}^{-1}\right)$, Glyphosate+Metsulfuron $\left(1800+4 \mathrm{~g} \mathrm{ha}^{-1}\right)$, Glyphosate+Saflufenacil $\left(1800+49 \mathrm{~g} \mathrm{ha}^{-1}\right)$.

\subsubsection{Herbicides in Triple Association}

The treatments consisted of an untreated control and the association of each combination of a broadleaf herbicide with the graminicides associated with glyphosate as follows: Glyphosate+2,4-D+Clethodim $(1800+1005+108 \mathrm{~g}$ $\left.\mathrm{ha}^{-1}\right)$, Glyphosate+2,4-D+Clodinafop $\left(1800+1005+60 \mathrm{~g} \quad \mathrm{ha}^{-1}\right), \quad$ Glyphosate+Metsulfuron+Cleclethodim $\left(1800+4+108 \quad \mathrm{~g} \quad \mathrm{ha}^{-1}\right), \quad$ Glyphosate+Metsulfuron+Clodinafop $\quad\left(1800+4+60 \quad \mathrm{~g} \quad \mathrm{ha}^{-1}\right)$, Glyphosate+Saflufenacil+Clethodim $\left(1800+49+108 \quad \mathrm{~g} \mathrm{ha}^{-1}\right), \quad$ and Glyphosate+Saflufenacil+Clodinafop $\left(1800+49+60 \mathrm{~g} \mathrm{ha}^{-1}\right)$.

\subsection{Proceedings}

When the weed species had approximately four leaves, the treatments were applied. For the application of the herbicides it was used a backpack $\mathrm{CO}_{2}$-pressurized backpack sprayer with a two meters wide boom with four tip nozzles 110.015 working at a constant pressure of $1.2 \mathrm{Kpa}$ calibrated to deliver 150 liters of water per hectare.

\subsection{Evaluated Variables}

The variable control was analyzed at 21 and 28 days after spray in a visual percentage scale from zero (0) to $100 \%$ comparing each treated plant with the correspondent untreated control of each level of association, where 
zero corresponded to no injury and $100 \%$ corresponded to plant's complete death. The variable dry weight was obtained at 28 days after spray by cutting each plant at the soil surface and placing it in paper bags to remain at constant flux drying chamber at $60^{\circ} \mathrm{C}$ for 72 hours until to reach constant weight.

\subsection{Research Design}

The experimental design adopted was a completely randomized with four replications. Each experimental unit consisted of a plastic pot containing one plant.

\subsection{Statistical Analysis}

The results were subjected to analysis of variance though the F test $(p \leq 0.05)$ and in case of significance the treatment means were subjected to Duncan's multiple range test $(p \leq 0.05)$ to sort out the means, using the statistical software Winstat v.2.0. The variable weed control was analyzed in a factorial arrangement, where for the isolated herbicides: six treatments and two weed species $(6 \times 2)$, for the double association 11 treatments and two weed species $(11 \times 2)$, and the triple association six treatments and two weed species $(6 \times 2)$. Looking for finding out the compatibility of the double herbicide association, control data of the isolated herbicides were subjected to the Colby's method (Colby, 1967) to calculate the expected control and to compare with the control promoted by the double herbicide association through the $t$ test $(p \leq 0.05)$. For the variable dry weight, it was analyzed as a single factor looking to find differences among treatments independently of the weed specie.

\section{Results and Discussion}

The control of Italian ryegrass with the herbicides sprayed alone at 21 days after treatment (DAT), the best control index was achieved with clethodim and clodinafop, although these levels were below the ideal. For horseweed, in this same evaluation time, the best control index was achieved with saflufenacil, followed by glyphosate and 2,4-D, respectively. At 28 DAT, horseweed reached a control index superior to $80 \%$ with the herbicides glyphosate, 2,4-D, metsulfuron and saflufenacil; whereas, Italian ryegrass was controlled by the herbicides clethodim and clodinafop at the same evaluation period. For the isolated herbicides, the result of the variable control was correspondent to the variable dry weight, in which generally the graminicides operated on the decrease of Italian ryegrass reduction and the broadleaf herbicides decreased lower dry weight for horseweed (Table 1). These results corroborate with the ones observed by Vargas et al. (2007) where glyphosate susceptible horseweed was effectively controlled by 2,4-D and metsulfuron at the same rates tested in this experiment; saflufenacil was the quickest treatment to control horseweed and consequently led to the smallest dry weight in all treatments that was present. Rockenbach, Schneider, and Bianchi (2015) reported that clodinafop was the herbicide which the Italian ryegrass plants had the greatest dry weight in comparison with other ACCase herbicides. This occurs because Italian ryegrass naturally presents more elevated tolerance to the effects of clodinafop compared to oats, thus allowing the plant to vegetate longer and so accumulating more dry weight (Ormeño \& Días, 1995).

Table 1. Control (\%) of Italian ryegrass (Lolium multiflorum) and horseweed (Conyza spp.), in function of the isolated herbicides, evaluated at 21 and 28 days after treatment (DAT) and dry weight (g) at 28 days after spray. Vacaria/RS, 2014

\begin{tabular}{|c|c|c|c|c|c|c|c|c|c|c|c|}
\hline \multirow{3}{*}{$\begin{array}{l}\text { Treatments } \\
2,4-\mathrm{D}^{1}\end{array}$} & \multirow{3}{*}{$\begin{array}{l}\begin{array}{l}\text { Rate } \\
\left(\text { g a.i. ha }^{-1}\right)\end{array} \\
1005\end{array}$} & \multicolumn{4}{|c|}{$21 \mathrm{DAT}$} & \multicolumn{4}{|c|}{28 DAT } & \multicolumn{2}{|c|}{ Dry Weight (g) } \\
\hline & & \multicolumn{2}{|c|}{ Italian ryegrass } & \multicolumn{2}{|c|}{ Horseweed } & \multicolumn{2}{|c|}{ Italian ryegrass } & \multicolumn{2}{|c|}{ Horseweed } & \multirow{2}{*}{$\frac{\text { Italian ryegrass }}{0.73 \mathrm{a}}$} & Horseweed \\
\hline & & 2 & $\mathrm{~B} \mathrm{c}^{2}$ & 80 & $\mathrm{Ac}$ & 2 & $\mathrm{~B} \mathrm{c}$ & 83 & $\mathrm{Ac}$ & & $0.16 \mathrm{~b}$ \\
\hline Clethodim & 108 & 44 & A a & 0 & $\mathrm{~B} \mathrm{e}$ & 86 & $\mathrm{~A} \mathrm{a}$ & 0 & $\mathrm{Bd}$ & $0.28 \mathrm{c}$ & $1.65 \mathrm{a}$ \\
\hline Clodinafop & 60 & 36 & $\mathrm{~A} a b$ & 0 & $\mathrm{~B} \mathrm{e}$ & 78 & $\mathrm{Aa}$ & 0 & $\mathrm{Bd}$ & $0.33 \mathrm{bc}$ & $1.96 \mathrm{a}$ \\
\hline Glyphosate & 1800 & 34 & $\mathrm{~B} \mathrm{~b}$ & 92 & $\mathrm{Ab}$ & 21 & $\mathrm{~B} \mathrm{~b}$ & 95 & $\mathrm{~A} a b$ & $0.54 \mathrm{ab}$ & $0.19 \mathrm{~b}$ \\
\hline Metsulfuron & 4 & 2 & $\mathrm{~B} \mathrm{c}$ & 61 & $\mathrm{Ad}$ & 3 & $\mathrm{~B} \mathrm{c}$ & 90 & $\mathrm{Abc}$ & $0.50 \mathrm{ab}$ & $0.22 \mathrm{~b}$ \\
\hline Saflufenacil & 49 & 3 & $\mathrm{~B} \mathrm{c}$ & 100 & $\mathrm{Aa}$ & 4 & $\mathrm{~B} \mathrm{c}$ & 100 & $\mathrm{~A} \mathrm{a}$ & $0.46 \mathrm{ab}$ & $0.02 \mathrm{c}$ \\
\hline Control & - & 0 & $\mathrm{Ac}$ & 0 & $\mathrm{Ae}$ & 0 & $\mathrm{Ac}$ & 0 & $\mathrm{Ad}$ & $0.68 \mathrm{ab}$ & $1.71 \mathrm{a}$ \\
\hline C.V. $(\%)^{3}$ & & 18. & & & & 14 & & & & 23.36 & 19.55 \\
\hline
\end{tabular}

Note. ${ }^{1}$ To the herbicides clodinafop it was added the adjuvant Assist ${ }^{\mathbb{R}}$ at $0.5 \% \mathrm{v} / \mathrm{v}$; to clethodim, Lanzar $^{\mathbb{B}}$ at $0.5 \%$ $\mathrm{v} / \mathrm{v}$ and to saflufenacil, Dash ${ }^{\circledR}$ at $0.5 \% \mathrm{v} / \mathrm{v} ;{ }^{2}$ Means followed by distinct upper case letters in the same line and lower case letters in the same column are statistically different according to the Duncan's multiple range test ( $\mathrm{p} \leq$ 0.05 ), on the comparison of Italian ryegrass and horseweed and the treatments respectively; ${ }^{3} \mathrm{C} . \mathrm{V} .=$ coefficient of variation. 
On the treatments with the association of two herbicides, there was significant interaction between treatment and the treated species. Italian ryegrass was not effectively controlled by glyphosate indicating that the evaluated biotype presents tolerance to the herbicide. The control of Italian ryegrass was effective with clethodim or clodinafop associated with the broadleaf herbicides at 21 and 28 DAT, with the exception of the association of clodinafop with 2,4-D, however, the variable dry weight for all the treatments significantly differed from the untreated control. It is important to point out that only on the association of clodinafop with 2,4-D there was antagonism to the control of Italian ryegrass as shown by the Colby's method (Table 2). Trezzi, Mattei, Vidal, Kruse, Gustman, Viola, Machado, and Silva (2007) reported from a greenhouse experiment with Italian ryegrass that 2,4-D associated with clodinafop only caused antagonism on the variable visual control when clodinafop was sprayed at rates inferior to $20 \mathrm{~g}$ a.i. ha $^{-1}$ associated to a fixed rate of $469 \mathrm{~g}$ a.i. ha ${ }^{-1}$ of 2,4-D. On the present experiment, it was used fixed rates of 60 and $1005 \mathrm{~g}$ a.i. ha ${ }^{-1}$ of clodinafop and 2,4-D, respectively, that represents a greater proportion of the broadleaf herbicide to the graminicide than the used by the authors. Even with greater rates than the observed, the rate of clodinafop was not sufficient to reverse the antagonism promoted by 2,4-D over the control of Italian ryegrass at 28 DAT.

According to Todd and Stobble (1989), the antagonism promoted by broadleaf herbicides over graminicides (ACCase inhibitors) when applied in association may be reverted through enhancing the rate of the graminicide, but this was not observed in the current experiment. In addition, the environmental conditions such as weed's hydric stress followed by the lack of rainfall on the days in the aftermath of the herbicide application, affect the capability of the graminicide to translocate in the leaves to the meristems (Gillespie \& Nalewaja, 1989; Todd \& Stobble, 1989; Trezzi et al., 2007; Palmer, Shaw, \& Holloway, 1999; Jordan, Frans, \& McClelland, 1993). For example, to maintain the control level of a Setaria spp. population at $80 \%$ with the herbicide $2,4-\mathrm{D}$, it was necessary to increase the rate of diclofop in $90 \%$ of the registered rate (Gillespie \& Nalewaja, 1989).

Alternatively, the antagonism may be reverted by spraying the broadleaf and the graminicides in different moments; York, Wilcut, and Grichar (1993) reported that the antagonism among 2,4-D and the graminicides clethodim, fluazifop, quizalofop and sethoxidim on the control of Digitaria sanguinalis and Urochloa spp. was fully reverted when the graminicides were sprayed 24 hours in advance of the broadleaf herbicide. In addition, Milton, Kurtz, and Shaw (1989) reported that the application of sethoxidim and quizalofop 24 hours prior to imazaquin, chlorimuron or lactofen did not cause any antagonism over the control of Echinochloa, but there was a control reduction of the grass when the graminicides were sprayed 24 hours after the broadleaf herbicides.

The chemical compounds of 2,4-D amine do not cause degradation of diclofop, thus there is no incompatibility between formulations, and the antagonism occurs in the action site in the plant. Diclofop tagged with radioactive carbon $\left({ }^{14} \mathrm{C}\right)$ associated with 2,4-D amine diminished the translocation rate of the graminicide in the leaf of an oat plant (Gillespie \& Nalewaja, 1989); in contrast, Todd and Stobble (1980) in an experiment with diclofop tagged with radioactive carbon associated with 2,4-D amine found that the quantity of the translocated diclofop did not decrease in relation to the isolated graminicide, but when associated with the hormonal herbicide, diclofop translocated in a greater quantity to the oat leaf apex and in reduced quantity to the oat plant's meristems, thus decreasing diclofop effectiveness to control the grass. O'Sullivan, Friesen, and Vander Born (1977) reported antagonism between diclofop and 2,4-D amine on the control of oats, but found no antagonism when the graminicide was associated with 2,4-D ester. According to the authors, the incompatibility was not due to the solvent present in the commercial formulations, but due to the incompatibility of active ingredients.

The association of metsulfuron with clethodim or clodinafop did not differ significantly between the control of Italian ryegrass and horseweed, although, there was antagonism caused by the graminicides on the control of horseweed as evidenced by the Colby's method (Table 2). This result corroborates with Darwent and Lefkovitch (1995), where the association of metsulfuron $\left(4.5 \mathrm{~g}\right.$ a.i. $\left.\mathrm{ha}^{-1}\right)$ to the graminicides fluazifop $\left(250 \mathrm{~g}\right.$ a.i. ha $\left.{ }^{-1}\right)$ or sethoxidim (500 g a.i. ha $\left.{ }^{-1}\right)$ did not affect the control of the grasses Hordeum jubatum L. and Bromus spp. Furthermore, similar results of this experiment were reported by Trezzi et al. (2007), in which rates above $20 \mathrm{~g}$ a.i. $\mathrm{ha}^{-1}$ of clodinafop associated with metsulfuron $\left(4 \mathrm{~g}\right.$ a.i. $\left.\mathrm{ha}^{-1}\right)$ controlled Italian ryegrass at levels above $80 \%$ in a greenhouse experiment.

There was antagonism between glyphosate and metsulfuron on the control of horseweed and synergism on the control of Italian ryegrass at 21 and 28 DAT as evidenced by the Colby's method (Table 2). The antagonism between glyphosate and the inhibitors of the acetolactate synthase (ALS) herbicides occurs possibly due to an alteration that the ALS herbicides promote on the translocation of glyphosate rather than molecules incompatibility, as the association of imazethapyr or chlorimuron with glyphosate may or may not present antagonism depending on the broadleaf species (Lich, Renner, \& Penner, 1997). 
Saflufenacil associated with clethodim or clodinafop did not cause any significant reduction on the control of any species evaluated in this experiment (Table 2). These results are similar to the ones reported by Jhala, Ramirez, Knezevic, Van Damme, and Sigh (2013), that the association of sethoxidim to saflufenacil controlled Setaria pumila and Echinochloa with no symptom of antagonism between the ACCase herbicides with saflufenacil, and the addition of saflufenacil to sethoxidim did not altered the control made by the broadleaf herbicide on dicot weeds.

Italian ryegrass dry weight on the treatment of glyphosate associated with clodinafop was significantly higher than at the treatment associated with clethodim (Table 2). The phenomena may have occurred due to the difference of formulation among adjuvants used to clethodim and clodinafop, as the addition of emulsifying oil to glyphosate do not affect the rate of absorption of the herbicide, but decreases up to $6 \%$ the rate of translocation (Eubank, Nandula, Reddy, Poston, \& Shaw, 2013).

The double association of glyphosate with saflufenacil, 2,4-D or metsulfuron, did not cause antagonism to horseweed control. In this experiment, saflufenacil was highly effective to control the species at 21 DAT. This result corroborates with Eubank et al. (2013), in which horseweed was fully controlled at 21 DAT by saflufenacil isolated at the same rate of this experiment, or associated with glyphosate $\left(1680 \mathrm{~g}\right.$ a.i. ha $\left.{ }^{-1}\right)$. According to the authors, saflufenacil do not interfere on the glyphosate absorption rate, although saflufenacil is a contact herbicide and causes a reduction rate of $6 \%$ of glyphosate translocation.

The association of 2,4-D (718 g a.i. ha $\left.{ }^{-1}\right)$ to glyphosate $\left(440 \mathrm{~g}\right.$ a.i. $\left.\mathrm{ha}^{-1}\right)$ did not present any antagonism on the control of $30 \mathrm{~cm}$ high horseweed and grasses such as Aegilops cylindrical and Bromus tectorum at tillering growth stage (Weise, Salisbury, Bean, \& Downy 1995). The author's results corroborate with the findings of this experiment, in which there was no horseweed control decrease through glyphosate associated with the hormonal herbicide. Additionally, the control of glyphosate susceptible horseweed is more effective when consummated on the growth stage up to six leaves, and the control quickness being prompted when in association of 2,4-D (Takano et al., 2013).

The control of horseweed with the association of glyphosate with metsulfuron was effective at 28 DAT, and the variable dry weight did not differ significantly of the association of glyphosate to 2,4-D (Table 2). In contrast, this result differs from Moreira, Melo, Carvalho, Nicolai, and Christoffoleti (2010), in which horseweed control through the association of glyphosate with metsulfuron $\left(1440+2 \mathrm{~g}\right.$ a.i. $\left.\mathrm{ha}^{-1}\right)$ did not differ from the untreated control. Nevertheless, this result might have happened due to the rates tested by the authors to be smaller and the weed's growth stage that the plants received the treatments was of ten leaves. 
Table 2. Control (\%) of biotypes of Italian ryegrass (Lolium multiflorum) and horseweed (Conyza spp.), in function of the association of two herbicides, evaluated at 21 and 28 days after treatments were applied (DAT) and dry weight (g) at 28 DAT. Vacaria/RS, 2014

\begin{tabular}{|c|c|c|c|c|c|c|c|c|c|c|c|c|c|c|}
\hline \multirow{3}{*}{$\begin{array}{l}\text { Treatments }^{1} \\
\text { 2,4-D+Clet. }\end{array}$} & \multirow{3}{*}{$\begin{array}{l}\text { Rate } \\
\left(\mathrm{g} \text { a.i. } \mathrm{ha}^{-1}\right) \\
1005+108\end{array}$} & \multicolumn{5}{|c|}{21 DAT } & \multicolumn{4}{|c|}{28 DAT } & \multicolumn{4}{|c|}{ Dry weight (g) } \\
\hline & & \multicolumn{2}{|c|}{ Ryegrass } & \multirow{2}{*}{$\frac{\mathrm{Cb}^{4}}{45+}$} & Horseweed & \multirow{2}{*}{$\frac{\mathrm{Cb}}{61+}$} & Ryegrass & \multirow{2}{*}{$\frac{\mathrm{Cb}}{66+}$} & Horseweed & \multirow{2}{*}{$\frac{\mathrm{Cb}}{90}$} & \multicolumn{2}{|c|}{ Ryegrass } & \multicolumn{2}{|c|}{ Horseweed } \\
\hline & & 71 & $\mathrm{~A} \mathrm{abc}^{2}$ & & $84 \mathrm{Aa}$ & & $83 \mathrm{~A} \mathrm{ab}$ & & $93 \mathrm{Aa}$ & & 0.13 & def & 0.16 & $\mathrm{c}$ \\
\hline 2,4-D+Clod. & $1005+60$ & 31 & $\mathrm{~B} \mathrm{e}$ & 37 & $79 \mathrm{~A} \mathrm{ab}$ & 61 & $48 \mathrm{~B} \mathrm{c}$ & 79- & $87 \mathrm{~A} \mathrm{a}$ & 90 & 0.27 & cde & 0.15 & $\mathrm{c}$ \\
\hline Gly.+Clet. & $1800+108$ & 93 & $\mathrm{~A} \mathrm{a}$ & $63+$ & $57 \mathrm{~B} \mathrm{bc}$ & 80 & $100 \mathrm{~A} \mathrm{a}$ & $73+$ & $82 \mathrm{Aa}$ & 83 & 0.06 & $\mathrm{f}$ & 0.12 & $\mathrm{~cd}$ \\
\hline Gly.+Clod. & $1800+60$ & 68 & A abc & $58+$ & $52 \mathrm{Acd}$ & 80 & $56 \mathrm{Abc}$ & 82 & $75 \mathrm{~A} \mathrm{a}$ & 83 & 0.28 & cde & 0.38 & $\mathrm{~b}$ \\
\hline Gly.+2,4-D & $1800+1005$ & 37 & B de & 35 & $89 \mathrm{Aa}$ & 92 & $74 \mathrm{~A} \mathrm{abc}$ & $23+$ & $97 \mathrm{Aa}$ & 98 & 0.46 & $a b c$ & 0.12 & $\mathrm{~cd}$ \\
\hline Gly.+Mets. & $1800+4$ & 76 & $\mathrm{~A} a b$ & $35+$ & $83 \mathrm{Aa}$ & $100-$ & $59 \mathrm{~B} \mathrm{bc}$ & $24+$ & $92 \mathrm{Aa}$ & $100-$ & 0.32 & bcd & 0.14 & $\mathrm{~cd}$ \\
\hline Gly.+Saflu. & $1800+49$ & 45 & B cde & 36 & $100 \mathrm{~A} \mathrm{a}$ & 100 & $53 \mathrm{~B} \mathrm{bc}$ & 25 & $100 \mathrm{~A} \mathrm{a}$ & 100 & 0.62 & $\mathrm{ab}$ & 0.01 & e \\
\hline Mets.+Clet. & $4+108$ & 66 & $\mathrm{Abc}$ & 45 & $35 \mathrm{~B} \mathrm{~cd}$ & $100-$ & $81 \mathrm{Aab}$ & 67 & 89 A a & $100-$ & 0.10 & ef & 0.33 & $\mathrm{~b}$ \\
\hline Mets.+Clod. & $4+60$ & 57 & A bcd & 37 & $27 \mathrm{~B} \mathrm{~d}$ & $100-$ & $77 \mathrm{~A}$ abc & 79 & $71 \mathrm{~A} \mathrm{a}$ & $100-$ & 0.10 & def & 0.14 & $\mathrm{~cd}$ \\
\hline Saflu.+Clet. & $49+108$ & 58 & B bcd & 45 & $100 \mathrm{~A} \mathrm{a}$ & 100 & $78 \mathrm{~A} a b c$ & 67 & $100 \mathrm{~A} \mathrm{a}$ & 100 & 0.16 & def & 0.02 & e \\
\hline Saflu.+Clod. & $49+60$ & 63 & B bcd & $37+$ & $100 \mathrm{~A} \mathrm{a}$ & 100 & 77 A abc & 79 & $100 \mathrm{~A} \mathrm{a}$ & 100 & 0.14 & def & 0.06 & $\mathrm{~d}$ \\
\hline Control & - & 0 & A f & 0 & $\mathrm{Ae}$ & 0 & $\mathrm{Ad}$ & & $\mathrm{Ab}$ & & 0.68 & a & 2 & $\mathrm{a}$ \\
\hline C.V. $(\%)^{3}$ & & 27. & & & & & 25.56 & & & & 31.68 & & 15.52 & \\
\hline
\end{tabular}

Note. ${ }^{1}$ To the herbicides clodinafop it was added the adjuvant Assist ${ }^{\mathbb{B}}$ at $0.5 \% \mathrm{v} / \mathrm{v}$; to clethodim, Lanzar $^{\mathbb{B}}$ at $0.5 \%$ $\mathrm{v} / \mathrm{v}$ and to saflufenacil, Dash ${ }^{\circledR}$ at $0.5 \% \mathrm{v} / \mathrm{v} ;{ }^{2}$ Means followed by distinct upper case letters in the same line and lower case letters in the same column are statistically different according to the Duncan's multiple range test ( $\mathrm{p} \leq$ $0.05)$, on the comparison of Italian ryegrass and horseweed and the treatments respectively; ${ }^{3} \mathrm{C} . \mathrm{V} .=$ coefficient of variation; ${ }^{4} \mathrm{Cb}=$ control estimated through the method described by Colby (1967), where "+" denotes synergism and "-" denotes antagonism between associations of herbicides, significant according to the $t$ test $(p \leq 0.05)$, in relation to the observed control . Clet $=$ clethodim; Clod = clodinafop; Gly = glyphosate; Mets = metsulfuron; Saflu $=$ saflufenacil.

On the triple association of glyphosate with saflufenacil and clethodim there was no significant control reduction, besides a low dry weight for horseweed and Italian ryegrass (Table 3). According to Jhala et al. (2013), the triple association of sethoxidim with saflufenacil and glyphosate was the treatment that provided the greatest grass control level. In opposition, on the present experiment the triple association of the herbicides glyphosate with saflufenacil and clodinafop provided significantly lower control, and elevated Italian ryegrass dry weight. It might have happened due to an antagonism between glyphosate and clodinafop, although it is not possible to determine it in function of the number of associations involved, as at the double association of saflufenacil with clodinafop there was a good control of Italian ryegrass and low dry weight, but glyphosate associated with clodinafop provided a control decrease for the specie.

Still on the triple association of herbicides, there was inferior horseweed control at 28 DAT in comparison to the others treatments, when clodinafop was associated with glyphosate and metsulfuron; Glyphosate associated with metsulfuron and clethodim presented significant decrease on the Italian ryegrass control and greater dry weight (Table 3). This decrease was caused by metsulfuron that interacted with the graminicide and diminishing its action, because when clethodim was associated with glyphosate, no control decrease was found for the grass. (Table 2). These results corroborate with Darwent and Lefkovitch (1995), in which metsulfuron in similar rate of the one tested in this experiment associated with sethoxidim or fluazifop decreased the control of the grass Bromus inermis L.

Various studies report about the antagonism herbicides of the group of the sulfonylurea with ACCase inhibitors (Jordan et al., 1993; Palmer et al., 1999; Blackshaw, Harker, Clayton, \& O'Donovan, 2006). Nevertheless, the antagonism of the sulfonylureas herbicides depends on the active ingredient combined, as Jordan (1995) found no antagonism between chlorimuron and clethodim on the control of Urochloa platyphylla, but there was a considerable control decrease when the graminicides used for the association was fluazifop, fenoxaprop or quizalofop. According to the author, it is likely that the antagonism occurs due to chemical reactions between the graminicides' molecules with the sulfonylurea ones, instead of weed physiological disorders provoked by the broadleaf herbicide. 
Table 3. Control (\%) of biotypes of Italian ryegrass (Lolium multiflorum) and horseweed (Conyza spp.), in function of the association of three herbicides, evaluated at 21 and 28 days after treatments were applied (DAT) and dry weight (g) at 28 DAT. Vacaria/RS, 2014

\begin{tabular}{|c|c|c|c|c|c|c|c|}
\hline \multirow{2}{*}{ Treatments } & \multirow{2}{*}{ Rate $\left(g\right.$ a.i ha $\left.{ }^{-1}\right)$} & \multicolumn{2}{|c|}{$21 \mathrm{DAT}$} & \multicolumn{2}{|c|}{$28 \mathrm{DAT}$} & \multicolumn{2}{|c|}{ Dry Weight (g) } \\
\hline & & Ryegrass & Horseweed & Ryegrass & Horseweed & Ryegrass & Horseweed \\
\hline $\mathrm{Gly}+2,4-\mathrm{D}+\mathrm{Cle}^{1 \& 4}$ & $1800+1005+108$ & $79 \mathrm{~B} \mathrm{a}^{2}$ & $99 \mathrm{~A} \mathrm{a}$ & $83 \mathrm{~B} \mathrm{a}$ & $99 \mathrm{~A} \mathrm{a}$ & $0.08 \mathrm{c}$ & $0.03 \mathrm{~cd}$ \\
\hline Gly+2,4-D+Clo & $1800+1005+60$ & $31 \mathrm{~B} \mathrm{c}$ & $100 \mathrm{Aa}$ & $16 \mathrm{~B} \mathrm{~d}$ & $100 \mathrm{~A} \mathrm{a}$ & $0.31 \mathrm{~b}$ & $0.01 \mathrm{~d}$ \\
\hline Gly+Met+Cle & $1800+4+108$ & $63 \mathrm{Ab}$ & $66 \mathrm{Ac}$ & $71 \mathrm{~B} \mathrm{~b}$ & $91 \mathrm{~A} \mathrm{ab}$ & $0.22 \mathrm{~b}$ & $0.17 \mathrm{~b}$ \\
\hline Gly+Met+Clo & $1800+4+60$ & $88 \mathrm{~A} \mathrm{a}$ & $75 \mathrm{~B} \mathrm{~b}$ & $86 \mathrm{~A} \mathrm{a}$ & $87 \mathrm{Ab}$ & $0.08 \mathrm{c}$ & $0.04 \mathrm{c}$ \\
\hline Gly+Saflu+Cle & $1800+49+108$ & $85 \mathrm{~B} \mathrm{a}$ & $100 \mathrm{~A} \mathrm{a}$ & $92 \mathrm{~A} \mathrm{a}$ & $100 \mathrm{Aa}$ & $0.03 \mathrm{c}$ & $0.03 \mathrm{~cd}$ \\
\hline Gly+Saflu+Clo & $1800+49+60$ & $57 \mathrm{~B} \mathrm{~b}$ & $100 \mathrm{~A} \mathrm{a}$ & $52 \mathrm{~B} \mathrm{c}$ & $100 \mathrm{~A} \mathrm{a}$ & $0.29 \mathrm{~b}$ & $0.01 \mathrm{~d}$ \\
\hline Control & - & $0 \mathrm{Ad}$ & $0 \quad \mathrm{Ad}$ & $0 \mathrm{~A} \mathrm{e}$ & $0 \quad \mathrm{Ac}$ & $0.64 \mathrm{a}$ & $2 a$ \\
\hline C.V. $(\%)^{3}$ & & 9.25 & & 10.82 & & 26.15 & 29.46 \\
\hline
\end{tabular}

Note. ${ }^{1}$ To the herbicides clodinafop it was added the adjuvant $\mathrm{Assist}^{\circledR}$ at $0.5 \% \mathrm{v} / \mathrm{v}$; to clethodim, Lanzar $^{\circledR}$ at $0.5 \%$ $\mathrm{v} / \mathrm{v}$ and to saflufenacil, Dash ${ }^{\circledR}$ at $0.5 \% \mathrm{v} / \mathrm{v} ;{ }^{2}$ Means followed by distinct upper case letters in the same line and lower case letters in the same column are statistically different according to the Duncan's multiple range test ( $\mathrm{p} \leq$ 0.05), on the comparison of Italian ryegrass and horseweed and the treatments respectively; ${ }^{3} \mathrm{C} . \mathrm{V} .=$ coefficient of variation.; ${ }^{4}$ Gly $=$ Glyphosate; Cle $=$ Clethodim; Clo = Clodinafop; Met $=$ Metsulfuron; Saflu = Saflufenacil .

\section{Conclusions}

The association of graminicides with broadleaf herbicides increases the weed control spectrum, but it depends of the herbicide used for association. When antagonism occurs, the herbicide that always has its effects reduced is the graminicide in detriment of the broadleaf herbicide. The herbicide clodinafop presents a control decrease of Italian ryegrass when associated with 2,4-D or glyphosate. When in association with glyphosate, metsulfuron decreases the control of Italian ryegrass provided by clethodim and glyphosate decreases horseweed control provided by metsulfuron, when in association.

\section{References}

Agostinetto, D., Rigoli, R. P., Schaedler, C. E., Tironi, S. P., \& Santos, L. S. (2008). Período crítico de competição de plantas daninhas com a cultura do trigo. Planta Daninha, 26(2), 271-278. https://doi.org/ 10.1590/S0100-83582008000200003

Blackshaw, R. E., Harker, K. N., Clayton, G. W., \& O’donovan, J. T. (2006). Broadleaf herbicide effects on clethodim and quizalofop-P efficacy on volunteer wheat (Triticum aestivum). Weed Technology, 20(1), 221-226. https://doi.org/10.1614/WT-04-059R.1

Colby, S. R. (1967). Calculating synergistic and antagonistic responses of herbicide combinations. Weed Science Society of America, 15(1), 20-22. https://doi.org/10.2307/4041058

Darwent, A. L., \& Lefkovitch, L. P. (1995). Control of several perennial weeds in creeping red fescue (Festuca rubra) grown for seed. Weed Technology, 9(2), 294-300. https://doi.org/10.1017/S0890037X0002337X

Eubank, T. W., Nandula, V. K., Reddy, K. N., Poston, D. H., \& Shaw, D. R. (2013). Saflufenacil efficacy on horseweed and its interaction with glyphosate. Weed Biology and Management, 13(4), 135-143. https://doi.org/10.1111/wbm.12022

Gillespie, G. R., \& Nalewaja, J. D. (1989). Influence of 2,4-D and MCPA formulations and oil on diclofop phytotoxicity. Weed Science, 37(3), 380-384. https://doi.org/10.1017/S004317450007209X.

Heap. (2017). Herbicide Resistant Weeds in Brazil. Retrieved from http://www.weedscience.org/Summary/ Country.aspx?CountryID $=5$

Jhala, A. J., Ramirez, A. H. M., Knezevic, S. Z., Van Damme, P., \& Sigh, M. (2013). Herbicide tank mixtures for broad-spectrum weed control in Florida citrus. Weed Technology, 27(1), 129-137. https://doi.org/10.1614/ WT-D-12-00105.1

Jordan, D. L. (1995). Influence of adjuvants on the antagonism of graminicidas by broadleaf herbicides. Weed Technology, 9(4), 741-747. https://doi.org/10.1614/WT-D-12-00105.1 
Jordan, D. L., Frans, R. E., \& McClelland, M. R. (1993). Interactions of DPX-PE350 with fluazifop-P, sethoxydim, clethodim, and quizalofop-P. Weed Technology, 7(3), 605-610. https://oi.org/10.1017/ S0890037X00037416

Lich, J. M., Renner, K. A., \& Penner, D. (1997). Interaction of glyphosate with postemergence soybean (Glicine max) herbicides. Weed Science, 45, 12-21.

Minton, B. W., Kurtz, M. E., \& Shaw, D. R. (1989). Barnyardgrass (Echinochloa crus-galli) control with grass and broadleaf weed herbicide combinations. Weed Science, 37(2), 233-227. https://oi.org/10.1017/ S0043174500071824

Moreira, M. S., Melo, M. S. C., Carvalho, S. J. P., Nicolai, M., \& Christoffoleti, P. J. (2010). Alternative herbicides to control glyphosate-resistant biotypes of Conyza bonariensis and C. canadensis. Planta Daninha, 28(1), 167-175. https://doi.org/10.1590/S0100-83582010000100020

Ormeño, J. N., \& Díaz, J. S. (1995). Clodinafop, a new herbicide for the selective controlo f grass weeds in wheat. I. Control efficacy on wild oats (Avena fátua), anual ryegrass (Lolium multiflorum), dogtailgrass (Cynosurus echinatus), and bulbous oatgrass (Arrhenatherum elatius spp. Bulbosum). Agricultura Técnica, 55(2), 106-117.

O’Sullivan, P. A., Friesen, H. A., \& Vander Born, W. H. (1977). Influence of herbicides for broad-leaved weeds and adjuvants with dichlorfop methyl on oat control. Canadian Journal of Plant Science, 57, 177-125. https://doi.org/10.4141/cjps77-018

Palmer, E. W., Shaw, D. R., \& Holloway, J. C. (1999). Influence of CGA-277476 on efficacy of postemergence graminicides. Weed Science, 13(1), 48-53. https://doi.org/10.1017/S0890037X00044894

Rockenbach, A. P., Schneider, T., \& Biachi, M. A. (2015). Ryegrass control derived from isolated application with herbicides association. Cientifica, 43(1), 30-36. https://doi.org/10.15361/1984-5529.2015v43n1p30-36

Takano, H. K., Oliveira Jr, R. S., Constantin, J., Biffe, D. F., Franchini, L. H. M., Braz, G. B. P., ... Gemelli, A. (2013). Effect of 2,4-D addition to glyphosate for difficult control weeds species. Revista Brasileira de Herbicidas, 12(1), 1-13. https://doi.org/10.7824/rbh.v12i1.207

Todd, B. G., \& Stobble, E. H. (1980). The basis of the antagonistic effect of 2,4-D on diclofop-methyl toxicity to wild oat (Avena fatua). Weed Science, 28(4), 371-377. https://doi.org/10.1017/S0043174500055508

Trezzi, M. M., Mattei, D., Vidal, R. A., Kruse, N. D., Gustman, M. S., Viola, R., ... Silva, H. L. (2007). Antagonismo das associações de clodinafop-propargyl com metsulfuron-methyl e 2,4-D no controle de azevém (Lolium multiflorum). Planta Daninha, 25(4), 839-847. https://doi.org/10.1590/S0100-835820070 00400021

Trezzi, M. M., Vidal, R. A., Patel, F., Miotto Jr, E., Debastiani, F., Balbinot, A. A., \& Mosquen, R. (2014). Impact of Conyza bonariensis density and establishment period on soybean grain yield, yield componentes and economic threshold. European Weed Research Society, 55, 34-41. https://doi.org/10.1111/wre.12125

Vargas, L., Bianchi, M. A., Rizzardi, M. A., Agostinetto, D., \& Dal Magro, T. (2007). Buva (Conyza bonariensis) resistente ao glyphosate na região sul do Brasil. Planta Daninha, 25(3), 573-578. https://doi.org/10.1590/ S0100-83582007000300017

Vargas, L., Roman, E. S., Rizzardi, M. A., \& Silva, V. C. (2005). Alteração das características biológicas dos biótipos de azevém (Lolium multiflorum) ocasionada pela resistência ao herbicida glyphosate. Planta Daninha, 23(1), 153-160. https://doi.org/10.1590/S0100-83582005000100018

Wiese, A. F., Salisbury, C. D., \& Bean, B. W. (1995). Downy brome (Bromus tectorum), jointed goatgrass (Aegilops cylindrica) and horseweed (Conyza canadensis) control in fallow. Weed Science, 9(2), 249-254. https://doi.org/10.1017/S0890037X00023290

York, A. C., Wilcut, J. W., \& Grichar, W. J. (1993). Interaction of 2,4-DB with postemergence graminicides. Peanut Science, 20, 57-61. https://doi.org/10.3146/i0095-3679-20-1-15

\section{Copyrights}

Copyright for this article is retained by the author(s), with first publication rights granted to the journal.

This is an open-access article distributed under the terms and conditions of the Creative Commons Attribution license (http://creativecommons.org/licenses/by/4.0/). 